\title{
ARTYKUtY
}

Klio. Czasopismo poświęcone dziejom Polski i powszechnym

PL ISSN 1643-8191, t. 52 (1)/2020, s. 59-87

(c) (1) $\Theta$

http://dx.doi.org/10.12775/KLIO.2020.004

Mateusz WyżGA*

\section{Miasta i migracje w Rzeczypospolitej przedrozbiorowej. Zarys problematyki}

\section{Cities, touns, and migration in pre-partition Poland: the outline of the problem}

Streszczenie: W badaniach nad historią społeczną ważną rolę odgrywały migracje wewnętrzne (głównie wiejsko-miejskie). Są one istotne zwłaszcza w realiach Rzeczypospolitej przedrozbiorowej. Państwo to cechowało się dominacją rolnictwa i przewagą liczbową małych miast. Badania nad procesami migracyjnymi w tym przypadku wymagają posłużenia się różnymi źródłami i metodami. Istotne jest zbadanie intencji migranta, sieci migracyjnych oraz rzeczywistego zapotrzebowania miast na nowych mieszkańców oraz siłę roboczą. Należy uwzględnić również obecność kobiet na rynku pracy. Obserwacja polityki migracyjnej miast powinna objąć ich funkcjonowanie w realiach systemu folwarczno-pańszczyźnianego, które (przynajmniej) formalnie ograniczało migracje chłopów.

Instytut Historii i Archiwistyki, Uniwersytet Pedagogiczny im. KEN w Krakowie, ul. Podchorążych 2, 30-084 Kraków, mwyzga@up.krakow.pl, nr ORCID: 0000-0002$-0049-4210$. 
Summary: Internal migration (especially rural-urban migration) played an important role in the social history. It was crucial especially in the background of the pre-partition Poland. This country was characterized by the dominance of agriculture and great number of small towns. Research on migration processes in this case requires the use of various sources and methods. It is important to examine the intentions of the migrant, migration networks and the real demand of towns for new residents and the workforce. The presence of women on the labor market should also be taken into account. Observation of urban migration policy should take into account their functioning in the realities of the farmserfdom system, which (at least) formally limited the migration of peasants.

Słowa kluczowe: migracje, miasto, okres przedprzemysłowy, sieci społeczne

Keywords: migration, town, preindustrial period, social networks

\section{Wstęp}

$\mathrm{M}$ igracje były istotnym elementem funkcjonowania miast doby przednowoczesnej ${ }^{1}$. Ich występowanie mogło warunkować dalsze istnienie zwłaszcza większych, liczących ponad 10000 mieszkańców ośrodków, zależnych od regularnych dopływów siły roboczej, żywności i surowców. Większe zaburzenia przynosily klęski elementarne, przede wszystkim wyludniające epidemie chorób zakaźnych ${ }^{2}$. Miast tej wielkości było na terenie Rzeczypospolitej przedrozbiorowej zaledwie kilka, co każe inaczej położyć akcent na obserwację przepływów ludnościowych. Celem artykułu jest przybliżenie, w jaki sposób badania nad migracjami przyczyniają się do nowego spojrzenia na miasta przedprzemysłowe, zwłaszcza na proces urbanizacji. Większość migracji była czasowa. Pełna ich liczba dla doby

1 Prezentowany tekst stanowi rozwinięcie uwag Autora zamieszczonych w: M. Wyżga, Ze wspótczesnych badań nad mobilnościa w Europie przednowoczesnej, „Przeszłość Demograficzna Polski" 2018, t. 40, s. 11-37; idem, Homo movens. Mobilność chtopów w mikroregionie krakowskim $w$ XVI-XVIII w., Kraków 2019, s. 31-83.

2 A. Walaszek, Migracje Europejczyków: 1650-1914, Kraków 2007, s. 53-63; zob. J. de Vries, European urbanisation 1500-1800, London 1984; J. Lucassen, L. Lucassen, P. Manning, Migration history: multidisciplinary approaches, w: Migration history in world history. Multidisciplinary approaches, eds. J. Lucassen, L. Lucassen, P. Manning, Leiden-Boston 2010, s. 3-38. 
przedprzemysłowej nie jest w zasadzie możliwa do uzyskania przez wzgląd na ich zmienność, różnorodność, nietrwałość, jak i nieprecyzyjne formy rejestracji ruchu wędrówkowego w materiale źródłowym. Istotne pozostaje, że w przypadku migracji do miast dochodziło głównie do przemieszczeń wewnętrznych (tzn. na obszarze danego kraju), w nieco mniejszym zaś stopniu zewnętrznych (tj. zagranicznych, chociaż te $-\mathrm{z}$ racji wysokiej nieraz kondycji majątkowej i umysłowej przybyszy - mogły w poważny sposób wpłynąć na pojawienie się nowych technologii, wiedzy i kapitału). Dalej, ze względu na kierunki przemieszczeń migracje można podzielić na miejsko-miejskie, wiejsko-miejskie i miejsko-wiejskie. Ich realizacji w społeczeństwie stanowym towarzyszyła często mobilność społeczna (pionowa), tj. zmiana w hierarchii. Dla części migrantów (dobrowolnych lub przymusowych) jesteśmy w stanie rozpoznać podłoże społeczne (sieć migracyjna wspierająca ich ruch wędrówkowy), które z reguły opierało się na więziach rodzinnych, towarzyskich lub zawodowych. Tworzące się między kolejnymi etapami wędrówki tzw. łańcuchy migracyjne pozwalały na przepływ informacji o możliwościach znalezienia pracy i zamieszkania w danym ośrodku. Wreszcie, migracje podzielimy na trwałe i długookresowe (mogły to być lata spędzone w służbie domowej lub na nauce rzemiosła, zwłaszcza kiedy migrant znajdował korzystne warunki do dalszego zamieszkania i założenia rodziny) oraz sezonowe (np. podejmowanie przez chłopów pracy w mieście zimą, kiedy w rolnictwie panował regres; odmiennie, w sezonie letnim drobniejsze mieszczaństwo przenikające na wieś dla uzyskania dodatkowych zysków z dobrze płatnej pracy przy żniwach). Na te procesy w poważnym stopniu wpływała z kolei cyrkulacja, tj. regularne przemieszczanie się między miejscem pobytu a danym miastem w celach np. handlowych, transportowych, religijnych czy rodzinnych (lub powiązanie tych aspektów) ${ }^{3}$.

Przeszło dwie dekady temu w histografii światowej zwrócono uwagę na rolę, jaką odegrały w gospodarce Europy przednowoczesnej tysiące małych miast związanych $\mathrm{z}$ wiejską okolicą więziami gospodarczymi,

3 A. Walaszek, op. cit., s. 58; J. Hayhoe, Strangers and neighbours: rural migration in eighteenth-century northern Burgundy, Toronto 2016, s. 80-84. 
społeczno-demograficznymi, a niekiedy i własnościowymi ${ }^{4}$ („dla większości Europejczyków małe miasto było ich najbardziej bezpośrednim i najważniejszym kontaktem ze światem miejskim, bez względu na to, czy tam mieszkali”) $)^{5}$. Europa Środkowo-Wschodnia stanowi fenomen i wyzwanie dla badaczy historii migracji. Decydowała o tym pewna odmienność systemów społecznych, mniejsze zaludnienie niż na zachodzie i południu kontynentu, bliskość Orientu. Uwarunkowania te sprawiły, że zasadnicza uwaga w tym artykule jest skierowana na typowe dla krajobrazu Rzeczypospolitej mniejsze miasta, pozostawiając na uboczu duże ośrodki, mające już niekiedy pokaźny zestaw opracowań.

\section{Stan badań}

Tematyka migracji ludności do dawnych miast stanowi obecnie ważny a niewyjaśniony dostatecznie w nauce światowej fragment historii społecznej. Uznawano do niedawna społeczeństwa przedprzemysłowe, zwłaszcza ich niższe warstwy społeczne, za mało mobilne. Wynikało to m.in. ze stopnia zaawansowania analiz masowych. Ogłoszone już jednak w latach 70. XX w. prace takich badaczy, jak Peter Laslett czy Lawrence Stone ${ }^{6}$, dowiodły, że wskaźniki migracji w dobie wczesnonowożytnej były zbliżone do znanych z XIX stulecia ${ }^{7}$. Współcześnie historycy zajmujący się tym zagadnieniem są zgodni, że społeczeństwa przedprzemysłowe były niekiedy wysoce mobilne. Regularnością cechowały się zwłaszcza przebiegające na stosunkowo niewielkim dystansie wiejsko-miejskie przepływy ludności, gwarantujące równoważenie ubytków demograficznych powodowanych

${ }^{4}$ Mimo że autorzy cytowanej pracy zwrócili uwagę także na obszary peryferyjne Europy, brakło spojrzenia na sytuację polską; P. Clark, Introduction, w: Small towns in early modern Europe, ed. P. Clark, Cambridge 1995, s. 1-21.

5 Ibidem, s. 2.

6 P. Laslett, Family life and illicit love in earlier generations, Cambridge 1977; L. Stone, The family, sex and marriage in England 1500-1800, New York 1977.

7 J. Lucassen, L. Lucassen, P. Manning, op. cit., s. 3-6; J. Grülich, Migrace mestskeho a vesnickeho obyvatelstva. Farnost Ceske Budejovice 1750-1824, Ceske Budejovice 2013, s. 6; A. Walaszek, op. cit.; M. Wyżga, Ze wspótczesnych badań..., s. 11-37. 
przez wysoką śmiertelność w ośrodkach miejskich ${ }^{8}$. Inspirująco na rozwój badań nad historią migracji wewnętrznych wpłynęły prace ujmujące zjawisko kompleksowo czy w długich pasmach czasowych ${ }^{9}$ lub opierające się na dokładniejszym materiale z XIX i XX w. ${ }^{10}$ Prace te na ogół dotyczyły jednak zachodu Europy. Od niedawna coraz popularniejsze stają się badania nad północą ${ }^{11}$ i środkowym wschodem kontynentu ${ }^{12}$. Uwaga badaczy jest kierowana w stronę niedocenianego kobiecego rynku pracy czy asymilacji migrantów w mieście ${ }^{13}$.

8 R. Grafe, Economic and social trends, w: The Oxford handbook of early modern European history, 1350-1750, vol. 1: Peoples and place, ed. H. Scott, Oxford 2015, s. 283.

9 D. Hoerder, Cultures in contact: world migrations in the second millennium, London 2012; K. J. Bade, Migration in European history, Oxford 2003; The encyclopedia of European migration and minorities. From the seventeenth century to the present, eds. K. J. Bade, P. C. Emmer, L. Lucassen, J. Oltmer, Cambridge-New York 2012; P. Manning, Migration in world history (themes in world history), New York 2005.

10 L. P. Moch, The pariahs of yesterday: Breton migrants in Paris, Durham 2012; eadem, Paths to the city: regional migration in nineteenth-century France, Michigan 1983; J. H. Jackson, Migration and urbanization in the Ruhr Valley, 1821-1914, Boston 1997; J. Hayhoe, op. cit.

11 M. Andersson, Migration i 1600-talets Sverige: Älvsborgs lösen 1613-1618, Malmö 2018; E. Viitaniemi, Urban seasonal workers and rural church constructions in eighteenth-century Finland, w: Migration and multi-ethnic communities. Mobile people from the late Middle Ages to the present, ed. M. Ojala-Fulwood, Berlin-Boston 2018, s. 147-168.

12 J. Grülich, Migračni strategie: Město, predměstí a vesnice na panstvi České Budějoviceve druhé polovině 18. Století, České Budějovice 2018; M. Wyżga, Homo movens...

13 Zob. np. Domestic service and the formation of European identity: understanding the globalization of domestic work, $16^{\text {th }}-21^{\text {st }}$ Centuries, ed. A. Fauve-Chamoux, Berno 2005; M. L. Nagata, Labor migration, family and community in early modern Japan, w: Women, gender and labour migration, ed. P. Sharpe, London-New York 2001, s. 60-84. W przypadku Polski warto zwrócić uwagę na: C. Kuklo, Kobieta samotna w spoteczeństwie miejskim u schytku Rzeczypospolitej Szlacheckiej. Studium demograficzno-spoteczne, Białystok 1998; por. R. Poniat, Stużba domowa w miastach na ziemiach polskich od potowy XVIII do końca XIX w. Warszawa 2014. O realiach wiejskich w późnośredniowiecznej Małopolsce zob. M. Kołacz-Chmiel, Mulier honesta et laboriosa. Kobieta w rodzinie chtopskiej późnośredniowiecznej Matopolski, Lublin 2018, s. 271-315. 
W Polsce badania koncentrowały się dotąd na wielkich migracjach w ostatnich dwóch stuleciach ${ }^{14}$. Do zjawiska tego we wcześniejszym okresie i w kontekście miasta nawiązywano w różnym stopniu przy okazji studiów nad poszczególnymi ośrodkami miejskimi. Opracowano także niektóre grupy etniczne oraz kwestię ich polonizacji bądź alienacji ${ }^{15}$, jak również zwrócono uwagę na szlachtę w mieście ${ }^{16}$. Istotne pozostają ujęcia tej problematyki w kontekście demograficznym ${ }^{17}$. W sposób szerszy, opierając się na rejestrach przyjęć nowych obywateli do prawa miejskiego, zjawisko napływu ludności do miast w Rzeczypospolitej zbadał Stanisław Gierszewski, jak

14 Wybrane elementy nowszych badań zawiera ostatni tom rocznika „Przeszłość Demograficzna Polski”, np. M. Machałek, Migracje ludności na Pomorzu Zachodnim w latach czterdziestych i pięćdziesiątych XX w. - przegląd literatury, „Przeszłość Demograficzna Polski” 2016, t. 38 (3), s. 107-130.

15 Zob. np. Z. Noga, Zróżnicowanie etniczne i wyznaniowe mieszczaństwa krakowskiego w XVI w., w: Między Zachodem a Wschodem. Etniczne, kulturowe i religijne pogranicza Rzeczpospolitej XVI-XVIII w., wyd. K. Mikulski, A. Zielińska-Nowicka, Toruń 2006, s. 122-128; W. Kowalski, Wielka imigracja. Szkoci w Krakowie i Matopolsce w XVI-pierwszej potowie XVII w. Kielce 2010. Wśród rozmaitych nacji w państwie łączącym wchód i zachód kontynentu rosła liczba Żydów wśród mieszkańców miast, których osiedlaniu tam sprzyjała szlachta i magnateria; M. Bogucka, H. Samsonowicz, Dzieje miast i mieszczaństwa w Polsce przedrozbiorowej, Wrocław 1986, s. 466-475.

${ }^{16}$ T. Zielińska, Szlacheccy wtaściciele nieruchomości w miastach XVIII w., Warszawa 1987; F. Kiryk, Szlachta w Bochni. Ze studiów nad spoteczeństwem miast górniczych w Matopolsce w XVI i w pierwszej potowie XVII stulecia, w: Spoteczeństwo staropolskie. Studia i szkice, t. 2, Warszawa 1980, s. 71-114; idem, Szlachta w Wieliczce na przetomie XVI i XVII w., „Studia Historyczne” 1982, R. 25, z. 1, s. 3-25; M. Wyżga, Der Krakauer Adel vom 16. bis zum 18. Jahrhundert, w: Krakau - Nürnberg - Prag: die Eliten der Städte im mittelalter und in der frühen neuzeit: herkunft, nationalität, mobilität, mentalität, hrsg. M. Diefenbacher, O. Fejtová, Z. Noga, Praha 2016, s. 155-172.

17 Zob. np. C. Kuklo, Demografia Rzeczypospolitej przedrozbiorowej, Warszawa 2009, s. 224-236, 261-267; idem, Rodzina w osiemnastowiecznej Warszawie, Białystok 1991; idem, Kobieta samotna...; idem, Gtówne kierunki migracji na ziemiach polskich do końca XVIII w., w: Migracje: dzieje, typologia, definicje, red. A. Furdal, W. Wysoczański, Wrocław 2006, s. 148-156; J. Baszanowski, Przemiany demograficzne w Gdańsku w latach 1601-1846, Gdańsk 1995; K. Mikulski, Putapka niemożności. Społeczeństwo nowożytnego miasta wobec procesów modernizacyjnych (na przyktadzie Torunia w XVII i XVIII w.), Toruń 2004; por. A. Zielińska-Nowicka, W poszukiwaniu lepszego jutra. Procesy migracyjne mieszkańców Torunia w I potowie XX w. Toruń 2006. 
również pośrednio dla tego obszaru Jaroslav Miller ${ }^{18}$. Wartość tego źródła w kontekście funkcjonowania dawnych miast polskich przybliżają również m.in. Kamila Follprecht czy Andrzej Janeczek ${ }^{19}$. Nadto można wymienić wiele badań szczegółowych ${ }^{20}$, jak również prac odnoszących się do zjawiska mobilności w Europie Środkowo-Wschodniej ${ }^{21}$.

\section{Problem źródeł}

Badacze historii miast z obszaru Rzeczypospolitej przedrozbiorowej mają do dyspozycji bogaty, nie do końca rozpoznany materiał źródłowy do migracji do miast przedprzemysłowych. Źródła te można podzielić na ilościowe (kwantytatywne) i jakościowe (kwalitatywne). Informacje odpowiednie do analizy masowej, spełniające wymóg powtarzalności i standaryzacji danych, znajdziemy przede wszystkim w materiale miejskim wytworzonym przez różne instytucje i zawierające niezbędny czynnik identyfikacyjny, a mianowicie dane o nazwisku migranta, stanie społecznym i cywilnym, zawodzie, sieci społecznej, pochodzeniu, a czasem o wieku przybysza czy o długości pobytu w mieście. Tu trzeba wskazać na wykorzystywane już od kilku dekad rejestry nowych obywateli miast, a więc jedynie mężczyzn, i to

18 S. Gierszewski, Obywatele miast Polski przedrozbiorowej, Warszawa 1973; J. Miller, Urban societies in East-Central Europe, 1500-1700, Aldershot 2008.

19 K. Follprecht, Kontynuacja edycji ksiag przyjęć do prawa miejskiego w Krakowie 1612-1800, w: Editiones sine fine, t. 1, red. K. Kopiński, W. Mrozowicz, J. Tandecki, Toruń 2017, s. 51-66; Album civium Leopoliensium: rejestry przyjęć do prawa miejskiego we Lwowie 1388-1783, t. 1-2, wyd. A. Janeczek, Poznań-Warszawa 2005.

20 Zob. np. A. Karpiński, Krakowski pótświatek $w$ XVI-XVII i w I potowie XVIII w. Uwagi o środowisku krakowskich prostytutek i sutenerów, w: Studia nad dziejami miast $i$ mieszczaństwa $w$ średniowieczu, t. 1, red. A. Czacharowski, Toruń 1996, s. 237-259; M. Kamler, Migracje ludności do dużch miast $w$ Koronie $w$ XVI-XVII w. w świetle materiatów sąów kryminalnych, w: Miasto, region, społeczeństwo. Studia ofiarowane Profesorowi Andrzejowi Wyrobiszowi w sześćdziesiątą rocznice Jego urodzin, red. E. Dubas-Urwanowicz, J. Urwanowicz, Białystok 1992, s. 69-78; R. Poniat, Wiek opuszczania rodzinnego gospodarstwa domowego $w$ dobie stanistawowskiej $w$ świetle zeznań sądowych, „Przeszłość Demograficzna Polski” 2014, t. 35, s. 7-40; por. Migracje: dzieje, typologia, definicje.

21 Via viatores quaerit. Mobilność społeczna w dziejach krajów Grupy Wyszechradzkiej, red. A. Teterycz-Puzio, L. Kościelak, E. Łączyńska, Słupsk 2016. 
posiadających już pewne znaczenie i majątek, a i przeważnie zamieszkałych już jakiś czas w danym mieście. W większych ośrodkach pełnoprawni obywatele stanowili ok. 30\% grupy mieszkańców osiadłych ${ }^{22}$. Rejestry te pozwalają jedynie na orientację w zakresie standardów migracyjnych elementu najważniejszego - z punktu widzenia ówczesnych władz - kupców i rzemieślników cenniejszych profesji. Rozpoznaje się dzięki nim ramy polityki migracyjnej władcy, właściciela miasta i poszczególnych komun miejskich ${ }^{23}$. Ten „czuły wskaźnik” pozwala na wstępne oszacowanie ruchliwości przestrzennej i społecznej w miastach przedprzemysłowych. Podnosi się jednak niebezpieczeństwa analizy danych z rejestrów nowych obywateli miast bez powiązania z innym typem źródeł, np. z księgami metrykalnymi, co jest jednak zajęciem pracochłonnym i dla lepszego efektu wymaga utworzenia relacyjnej bazy elektronicznej ${ }^{24}$. Spisy przyjmujących prawo miejskie są jednak źródłem o niebagatelnej wartości, wyróżniającej się trwałą formą, możliwe do komparatystyki między różnymi ośrodkami, pisanym w epoce, gdzie statystyka poza księgowością metrykalną była w powijakach ${ }^{25}$.

O ile możliwe jest w przypadku elit miejskich odtworzenie procesów migracyjnych za pomocą nośnych przykładów, o tyle charakterystyka przepływów ludnościowych na rynku pracy wymaga zarówno ujęć masowych, jak i rozpoznania wielu zjawisk typowych dla migracji (sieć społeczna, uwarunkowania życia i intencje migranta, jego miejsce w cyklu życia podczas przemieszczenia, stan społeczny itp.). Trudność opracowania kwantytatywnego i porównawczego między poszczególnymi miastami wynika nie tylko z niedoboru materiałów o charakterze spisowym, ale też z różnie prowadzonych i zachowanych archiwaliów (np. luki chronologiczne, formy rejestracji przybyszy w zależności od ośrodka miejskiego). Na wytworzenie

22 M. Bogucka, H. Samsonowicz, op. cit., s. 465.

23 Mowa o tym również we wstępach wydawców ksiąg przyjęć do prawa miejskiego, np. A. Kiełbicka, Wstęp, w: Księgi przyjęć do prawa miejskiego w Krakowie 1507-1572. Libri iuris civilis Cracoviensis, wyd. A. Kiełbicka, Z. Wojas, Kraków 1993, s. VII-XVIII; zob. Album civium Leopoliensium...

24 S. Gierszewski, op. cit., s. 10-11, 15-31.

25 Ostatnio: K. Follprecht, Kontynuacja edycji ksiag ...; por. C. Kuklo, Demografia Rzeczypospolitej..., s. 261-267. 
się i stan zachowania źródeł po części wpływała wielkość i funkcje poszczególnych miast ${ }^{26}$.

Istotną grupę źródeł miejskich rejestrujących niekiedy dość szczegółowo przybyszy stanowią listy dobrego urodzenia ${ }^{27}$ oraz tzw. genealogie (zeznania na ogół dwóch świadków o legalnym pochodzeniu migranta) ${ }^{28}$ osób starających się np. o obywatelstwo miejskie czy angaż w rzemiośle. Mogą być one zawarte w księgach magistratu oraz w spuściźnie po cechach. $\mathrm{Na}$ przykład w Krakowie niektóre korporacje zawodowe gromadziły tego typu informacje w swych księgach, ale ok. 2500 zaświadczeń o przybyszach do nauki w zawodach spożywczych zawarto w księgach wójtowskich z lat 1647-173029. W poszukiwaniu migrantów można również wykorzystać

26 M. Bogucka, H. Samsonowicz, op. cit., s. 353-453.

27 A. Janeczek, Listy dobrego urodzenia $i$ dobrej stawy $w$ procedurze nadawania prawa miejskiego Lwowa w XV w., „Klio. Czasopismo Poświęcone Dziejom Polski i Powszechnym" 2012, t. 23 (4), s. 89-116.

28 J. Bieniarzówna, Chtopi w rzemiośle krakowskim w XVII w., „Przegląd Historyczny” 1956, t. 46 (3), s. 497-514.

29 Przykładem zawartości informacyjnej zeznań, zwłaszcza w kontekście funkcjonowania relacji społecznych i gospodarczych, są dwa zeznania w sprawie Pawła Zegadłowica, chłopskiego syna z Jasienia (zapewne chodzi o wieś koło miasta Żytomierz, 64,8 km na północ od Krakowa), przebywającego w Krakowie w 1670 r. Pierwszy świadek, obywatel Krakowa Maciej Gołkowic, zeznawał: „Rodziłem się ja też niedaleko tej wsi Jasinia, skąd jest ten Pan [sic!] Paweł, bośmy z sobą do szkoły chodzili, i znałem dobrze rodziców jego, i wiem że w stanie świętym małżeńskim spłodzili tego Pawła, który jest średnim, bo był starszy brat jego Krzysztof, a zaś po Pawle Wojciech. Ojciec ich był na roli w Jasieniu, Michał miał żonę Annę Milewione ze wsi Woli, już rodzice tych pomarli niedawno”. Drugi świadek, również obywatel krakowski, Marcin Bernatowic, wskazywał: „Znałem i ja z dawności rodziców tego Pawła, i braci jego znam dobrze, bom tam się blisko rodził i sam, i wiem że w stanie świętym małżeńskim żyjąc ojciec jego imieniem Michał Zegadłowic na roli był w Jasieniu, żonę miał imieniem Annę, i tego Pawła średniego spłodził, a jeszcze jest brat starszy i zaś młodszy drugi, tam mieszkają we wsi Jegomości Pana [Maiora], a ten to się już okupił z poddaństwa panom, rodzice jego już pomarli”. Z treści zapiski wynika, że obaj świadkowie byli z pochodzenia chłopami z okolicy wnioskodawcy i osiągnęli znaczny awans w Krakowie, stając się jego obywatelami. Oprócz wspólnego miejsca pochodzenia świadectwa opierały się na wspólnym uczęszczaniu do szkoły (zapewne parafialnej), na znajomości rodziców i rodzeństwa migranta. Uwagę zwraca tytułowanie migranta ze wsi honorującymi predykatami „Pan” oraz honestus (szanowany), jak również to, że samodzielnie wykupił się z poddaństwa swym panom; Archiwum Narodowe w Krakowie (dalej 
źródła podatkowe (szos) zestawiające właścicieli nieruchomości i zamieszkujących je osób, a czasem informacje o emigracji płatnika. Ruch wahadłowy ludności oddają księgi kluczników miejskich (bramne), a w szczególności rejestry celne towarów przewożonych przez miasto ${ }^{30}$. Ujęcie masowe, pod warunkiem zachowania należytej ostrożności badawczej, można przygotować w odniesieniu do ksiąg kryminalnych, zawierających protokoły przesłuchań osób oskarżonych i poszkodowanych. Pozwalają one przede wszystkim na ujęcie w badaniach kobiet. Ogólnie frekwencja tej płci w materiale źródłowym jest zaniżona, w pewnym sensie ze względu na jej niesamodzielność prawną, jednak nie powinno to odżegnywać od podejmowania wyzwań badawczych ${ }^{31}$.

Pozostawiając w tym miejscu źródła do migracji w lepiej rozpoznanych większych miastach, warto przyjrzeć się sytuacji w mniejszych ośrodkach, jakie dominowały w Rzeczypospolitej przedrozbiorowej (o czym niżej). Przeszkodą jest to, że częstokroć sprawy były w nich pisane łącznie, zapiski są przemieszane, co utrudnia użycie metod kwantytatywnych. Jednak wielość i podobieństwo spraw dziejących się w miasteczkach, podobny model ustrojowy tych ośrodków pomaga w wyjaśnianiu szerszych trendów migracyjnych. Przykładowo dla orientacji w kwestii zasięgu przestrzennego rekrutacji do cechów można wykorzystać spisy uczniów przyjmowanych i wyzwalanych w poszczególnych miastach. Trudno jednak bez uwzględnienia innego typu zapisek zweryfikować pochodzenie i długość pobytu migranta w mieście. Na przykład biorąc księgę cechu wielkiego w Bieczu z lat 1626-1784 (cech ów grupował siedem różnych zawodów), znajdziemy w niej krótkie wpisy uczniów u poszczególnych mistrzów. Jedynie co dziesiąty kandydat miał określone pochodzenie. Zwykle widnieją

ANK), Akta Miasta Krakowa, Advocatalia Cracoviensia, sygn. 259, s. 843; por. M. Wyżga, Homo movens..., s. 96-111.

30 Zob. np. P. Miodunka, Zaopatrzenie aglomeracji krakowskiej $w$ żywność $w$ potowie XVII w.: zarys problemu, w: Kraków - metropolia, t. 3: Dziedzictwo, red. J. Purchla, Kraków 2017, s. 7-30; J. M. Małecki, Studia nad rynkiem regionalnym Krakowa w XVI w., Warszawa 1963.

31 Zob. np. A. Karpiński, Krakowski pótświatek...; M. Kamler, Struktura i liczebność środowisk przestępczych Poznania i Krakowa w drugiej potowie XVI w., „Przeszłość Demograficzna Polski” 1984, t. 15, s. 79-85. 
przy uczniach imiona ich rodziców, niekiedy bez podanego zawodu i stanu społecznego. Z kolei pojawiające się sformułowanie „rodzicz” przy uczniu oznaczało zapewne, że była to osoba urodzona w Bieczu, co pomaga ustalić liczbę rodowitych mieszkańców w rzemiośle. Wiadomo dalej, że rodzice spoza miasta najczęściej posyłali tylko jednego syna do rzemiosła w Bieczu, rzadziej dwóch (najwięcej czterech) ${ }^{32}$. Z analizy bieckich wpisów (prowadzonych regularnie jedynie do wojny polsko-szwedzkiej z połowy XVII w.) wynika, że w trakcie dwóch dekad zarejestrowano ok. 100 przybyszy $^{33}$. Wzięcie podobnych źródeł z różnych miast przybliży nas do nakreślenia zasięgu i szlaków migracyjnych młodzieży płci męskiej profesjonalizującej się w rzemiośle.

Nierzadko dość niechlujny sposób prowadzenia zapisek cechowych w małym mieście utrudnia analizę. Przykładem jest księga cechowa z miasteczka Dobczyce, gdzie udało się zidentyfikować jedynie ok. 20 miejscowości (okolicznych wsi i miasteczek małopolskich), skąd napłynęli uczniowie ${ }^{34}$. Jednak w księdze cechu rzeźników królewskiego miasta Proszowice, stanowiącego centrum żyznej krainy rolniczej, tylko sporadycznie zapisywano pochodzenie uczniów. W ten sposób sprawa nie budzi wątpliwości przy niejakich Stanisławie Rzepce, Wojciechu Kopczyku i Janie Czerniku (1677-1680), chłopcach wywodzących się z oddalonego o ok. $18 \mathrm{~km}$ miasteczka Skalbmierz. Ale pochodzenie nie jest już takie pewne przy Marcinie Oświęcimskim (1700). Można się jedynie domyślać, że ten odmiejscowy antroponim wyparł wcześniejsze nazwisko i został urobiony od śląskiego miasta, oddalonego o $90 \mathrm{~km}$, gdzie ów Marcin zapewne przyszedł na

32 ANK, sygn. DEP 446, Księga cechu wielkiego w Bieczu 1626-1784, s. 22, 34.

33 Wśród podanych miejscowości pochodzenia chłopców, którzy przynajmniej na kilka lat przenieśli się do Biecza, znajdują się wsie, jak też miasta z Polski południowej (Chrzanów, Dębowiec, Dobczyce, Gorlice, Grybów, Jasło, Kraków, Krosno, Lublin, Sącz, Słomniki, Zakliczyn); ANK, sygn. DEP 446, Księga cechu wielkiego w Bieczu 1626-1784 , passim.

34 ANK, sygn. DEP 74, Książka ku przyjmowaniu uczniów rzemiosła kowalskiego, garncarskiego i ślusarskiego... [Dobczyce, 1578-1611]. Są to na ogół wsie i miasteczka z zasięgu kilkudziesięciu kilometrów (np. wsie: Droginia Rajsko, Rudnik, Stadniki; miasta: Nowa Góra, Nowy Targ, Przecław, Sącz, Uście Solne, Wadowice, Żabno). 
świat ${ }^{35}$. Nauka rzemiosła łączyła się z podróżami terminujących uczniów między miastami, co nazywało się „wandrem” ${ }^{36}$.

W zasadzie wiadomości o migrantach znajdują się prawie w każdym typie źródeł, jednak tu warto zwrócić jeszcze raz uwagę na księgi kryminalne, gdzie w protokołach przesłuchiwanych osób często można napotkać intencje migrantów odnoszące się do zmiany miejsca zamieszkania i poszukiwania lepszych szans na życie ${ }^{37}$. W ten sposób źródło to można wykorzystać zarówno kwalitatywnie, jak i kwantytatywnie. O roli administracji miejskiej w zjawisku migracji pozwala się zorientować materiał wytworzony przez urzędy miejskie, a zwłaszcza uchwały rad miejskich (wilkierze). Żmudna praca towarzyszy spożytkowaniu materiału testamentowego, który może jednak przybliżyć do odtworzenia np. sieci społecznej testatora (pochodzenie dłużników, kontrahentów, spadkobierców) ${ }^{38}$.

$\mathrm{Z}$ materiałów sporządzonych przez władze państwowe trzeba wskazać spisy ludności, zachowane jednak głównie dla schyłku epoki przedprzemysłowej i nie dla wszystkich obszarów rzeczypospolitej wykorzystywane przy badaniu społeczeństwa miast polskich przez Cezarego Kuklę ${ }^{39}$, a w przypadku wsi głównie przez Mikołaja Szołtyska ${ }^{40}$. Dzięki nim można odtworzyć skład rodzinnych gospodarstw domowych i przepływy jednostkowe

35 ANK, sygn. 324 [Księga cechu rzeźników w Proszowicach, 1653-1779], s. 3-4, 7.

36 Np. Jacenty Padzienski pochodzący z karczmy Sokołowskiej w Podkoszyczkach, osadzie przy królewskim mieście Koszyce koło nadwiślańskiego portu w Morsku, terminował zawód rzeźnika w Krakowie, ale został wyzwolony w oddalonych o $22 \mathrm{~km}$ Proszowicach; ANK, sygn. 324 [Księga cechu rzeźników...], s. 67 (1726). Ów Padzienski nie widnieje w spisach genealogii uczniów w krakowskich księgach wójtowskich tego czasu.

37 R. Poniat, Ludzie luźni w spoteczeństwie Rzeczypospolitej szlacheckiej w kontekście badań nad cyklem życia, „Roczniki Dziejów Społecznych i Gospodarczych” 2013, t. 73, s. $51-77$.

38 Również w testamentach chłopskich pojawiają się odniesienia do miast; zob. Testamenty chtopów polskich od drugiej potowy XVI do XVIII w., oprac. i wyd. J. Łosowski, Lublin 2015.

39 C. Kuklo, Kobieta samotna...

40 M. Szołtysek, Rethinking East-Central Europe: family systems and co-residence in the Polish-Lithuanian Commonwealth, vol. 1-2, Bern 2015; zob. także: E. Kaźmierczyk, Rozmieszczenie ludności powiatu proszowickiego pod koniec XVIII w. na podstawie spisów Komisji Porządkowej Cywilno-Wojskowej, „Przeszłość Demograficzna Polski” 2016, t. 38 (4), s. 37-62. 
między nimi, a także kolejność opuszczania domu rodzinnego przez młodzież. W księgach szlacheckich sądów grodzkich i ziemskich można odnaleźć procesy między szlachtą a miastami o nielegalne migracje chłopów, tj. bez uzyskania libertacji czyli zwolnienia z poddaństwa ${ }^{41}$. Wskazano już na przydatność ksiąg metrykalnych, prowadzonych powszechnie na ziemiach polskich od czasów soboru trydenckiego (1545-1563) ${ }^{42}$. Notacja ślubów, chrztów i zgonów ułatwia ustalenie zarówno przemieszczeń, jak i względnej stabilizacji migranta ${ }^{43}$.

Wydaje się, że większość migrantów w miastach, jacy zasilali szeregi plebsu i marginesu, a nie podlegali formalnej rejestracji, wywodziła się spośród ludności wiejskiej. Przyjmuje się, że robotnicy niewykwalifikowani cechowali się wysoką mobilnością. W tym aspekcie dla obszarów wiejskich dobrze orientuje Anna Kamler, co można w pewnym stopniu odnieść do sytuacji w miastach ${ }^{44}$. Sprawa nie zawsze jest oczywista z racji ubóstwa źródłowego. Przykładowo w leżącym ok. $80 \mathrm{~km}$ na wschód od Lwowa prywatnym mieście Pomorzany kontrakty dla pracowników folwarku w Hodowie zawierały jedynie nazwiska i wysokość wynagrodzenia dla parobków ${ }^{45}$. Nieco więcej informacji przyniosły rachunki renowacji fosy okalającej miasto Pomorzany z 1690 r. Jednak i tutaj tylko część robotników została określona przez swoje pochodzenie ${ }^{46}$. Wiadomo skądinąd o licznych migracjach

41 Próbę taką podjęła A. Kiełbicka, Zbiegostwo chtopów w województwie krakowskim na przetomie XVI i XVII w., Wrocław 1989.

42 C. Kuklo, Staropolska rejestracja ślubów, chrztów i pogrzebów w warsztacie badawczym historyka, w: Cztowiek w teatrze świata. Studia o historii i kulturze dedykowane Profesorowi Stanistawowi Grzybowskiemu z okazji osiemdziesiątych urodzin, red. B. Popiołek, Kraków 2010, s. 38-52.

43 C. Kuklo, Demografia Rzeczypospolitej..., s. 66-74, 91-129.

44 A. Kamler, Chtopi jako pracownicy najemni na wsi matopolskiej w XVI i pierwszej potowie XVII w., Warszawa 2005.

45 ANK, sygn. AD Pom 81.

$46 \mathrm{Z}$ zestawienia wynika, że przy naprawie fosy pracowała podobna liczba mężczyzn i kobiet (w tym małżeństwa), chociaż kobiety miały trzykrotnie mniejsze wynagrodzenie dniówkowe; ANK, sygn. AD Pom 48, s. 89. 
(legalnych i nielegalnych) ludności z centralnych części Rzeczypospolitej przedrozbiorowej do majątków kresowych i dalej ${ }^{47}$.

Chłopi stanowili nieodłączny element życia miasta, zapisywani np. w rejestrach wydatków w większych ośrodkach na prace porządkowe jako „laboriosi”, co świadczy o ich sezonowych napływach. Wskazuje się, że proces wtórnego poddaństwa nie zatrzymał migracji chłopów do miast w Rzeczypospolitej ${ }^{48}$. Tylko nieliczni spośród nich mieli szansę (i zamiar) osiągnięcia pełni praw mieszczańskich, co wiązało się z wysokimi kosztami i osiadłością na terenie miasta. Tym niemniej Stanisław Gierszewski, który oparł swe badania na wydanych do ok. 1973 r. rejestrach przyjęć do prawa miejskiego, obliczył, że nowi obywatele miast polskich o wiejskich korzeniach stanowili np. w Gdańsku w latach 1558-1793 aż 29\% mieszczan, w Chojnicach (1551-1770) 26\%, w Starej Warszawie (1506-1575) 50\%, w Przemyślu (1541-1660) 38\%, a w Bieczu (1538-1687) aż 63\% ${ }^{49}$. Należy przy tym sądzić, że nie wszyscy przybysze ze wsi mogą być zidentyfikowani z racji zmiany społecznej, dokonującej się przez lata między emigracją z domu rodzinnego a przyjęciem obywatelstwa miejskiego. Zapewne wielu migrantów bez podanego pochodzenia w rzeczywistości wywodziło się z rodzin chłopskich, co może wpłynąć na wysokość znanych już szacunków ${ }^{50}$.

Istotne pozostają takie kwestie, jak interesowność migracji do miast w warunkach poddaństwa, gdyż ono prócz wymogów związanych z darmową pracą odrobkową na folwarku oferowało chłopom pewne zabezpieczenia socjalne, skłaniając ludzi bez zaplecza społecznego i finansowego do

47 S. Śreniowski, Zbiegostwo chtopów w dawnej Polsce jako zagadnienie ustroju spotecznego, Warszawa 1948.

${ }^{48}$ M. Bogucka, H. Samsonowicz, op. cit., s. 385-387, 466; J. Ptaśnik, Miasta i mieszczaństwo w dawnej Polsce, wyd. 2, Warszawa 1949, s. 293-294.

49 S. Gierszewski, op. cit., s. 102, 95-116. Maarten Prak, analizując obywatelstwo miejskie, ujął nie tylko mieszczan uprzywilejowanych, ale i długoterminowych mieszkańców; M. Prak, Citizens without nations. Urban citizenship in Europe and the world, c. 1000-1789, Cambridge 2018.

${ }^{50}$ S. Gierszewski, op. cit., s. 9-11, 15-31, 52-55; M. Bogucka, H. Samsonowicz, op. cit., s. 391. W Krakowie w XVI-XVIII w. było to ok. 20\% obywateli, wywodzących się przeciętnie z odległości 44,4 km (mediana); M. Wyżga, Homo movens..., s. 56-59, 353-363. 
pozostania na wsi. Dalej, rozpoznanie praktyk migracyjnych i czynników wpływających na decyzję o przemieszczeniu do miasta. Poza materiałem miejskim informacje jakościowe o chłopach migrujących do miast można odnaleźć w księgach sądowych wiejskich, jak również w przywołanych już księgach sądów szlacheckich. Dotyczą one np. wprowadzania zapisów o legalnym odejściu poddanego z dóbr ziemskich szlachty czy duchowieństwa za ich zgodą i spełnieniem określonych warunków np. finansowych. Zdarzało się, że chłop taki był już od dłuższego czasu mieszkańcem miasta, a wcześniejsze zezwolenie pana na odejście poddanego było formą inwestycji długoterminowej (migrant był w stanie opłacić żądaną stawkę za zwolnienie $\mathrm{z}$ poddaństwa dopiero po dorobieniu się $\mathrm{w}$ mieście $)^{51}$.

Jak już nadmieniono, problemem jest ustalenie prawdziwej tożsamości migrantów. Osoby takie bowiem często były rejestrowane na aktualnym etapie migracji, bez wszystkich niezbędnych informacji pozwalających na jego identyfikację. Powoduje to, że uzyskana liczba migrantów musi być uznana za minimalną, gdyż nie wiadomo, jak wielu z nich przeszło już naturalizację w nowej przestrzeni społecznej. Niepewnym tropem jest analizowanie antroponimów odmiejscowych noszonych przez potencjalnych, osiadłych w mieście migrantów ${ }^{52}$. Wymaga to jednak dodatkowego potwierdzenia źródłowego. Można sądzić, że brak informacji o pochodzeniu migranta w mieście wynikał nie tyle z tuszowania różnic kulturowych, ile z powszechności tego zjawiska i nieprzykładania do tego większej wagi przez rejestrujących to pisarzy, którzy nie podawali miejsca pochodzenia np. służących ze wsi, utożsamiając miejsce pracy z miejscem zamieszkania ${ }^{53}$.

51 Więcej na ten temat: W. Dworzaczek, „Dobrowolne” poddaństwo chtopów, Warszawa 1952; S. Śreniowski, Zbiegostwo...

52 Próby takie są jednak podejmowane. Na negatywne postrzeganie i nazywanie przybyszy w społecznościach lokalnych wskazuje praca: K. D. M. Snell, Parish and belonging. Community, identity and welfare in England and Wales, 1700-1950, Cambridge-New York 2006, s. 42-43. We wczesnonowożytnym japońskim Kioto migranci osiadli w mieście umieszczali z kolei w nazwach szyldów swych zakładów nazwy osad, skąd się wywodzili. Mogło to sprzyjać odtwarzaniu się więzi społecznych z innymi migrantami, wywodzącymi się z tej samej okolicy; M. L. Nagata, Migration and networks in early modern Kyoto, Japan, „International Review of Social History” 2002, vol. 47, s. 243-259.

53 M. Kołacz-Chmiel, Mulier honesta..., s. 309-310; por. A. Głowacka-Penczyńska, Kobieta $w$ matych miastach Wielkopolski $w$ drugiej potowie XVI $i$ w XVII w., Warszawa 
Trudno też o rejestrację osób przechodnich w miasteczkach, o czym pośrednio dowiadujemy się z zapisów, że mieszczanie urządzali w swych posesjach „domy szynkowne”, w których „trafi się rozmaity gośc” ${ }^{4}$. Podobnie chłopi we wsiach przy głównych drogach świadczyli usługi noclegowe. Podsumowując tę część rozważań, należy podkreślić, że ani nieraz wieloletnie luki w materiale źródłowym (co doskwiera zwłaszcza przy budowaniu baz danych), ani problemy identyfikacji jednostek czy dokładnego momentu przybycia migranta do miasta, jak i uchwycenie danej osoby w kontekście różnych źródeł nie powinny zniechęcać przed podejmowaniem nowych prób ukazania pejzażu migracyjnego w miastach.

\section{Migracje i dawne miasto}

Podjęta tematyka ma związek z podziałem ludności na miejską i wiejską, a więc z procesem urbanizacji. Zjawisko to pozostaje jednak głównie w sferze szacunków dla realiów Rzeczypospolitej przedrozbiorowej, co wynika przede wszystkim z ubóstwa źródeł masowych dla epoki prestatystycznejej. Trzeba jednak podkreślić, że bez migracji nie doszłoby do postępów akcji lokacyjnej i dalszego istnienia większych miast na omawianym obszarze. Pełniły one różne funkcje, jednak wiele miast było niewielkimi ośrodkami agrarnymi, co prawda dysponującymi prawem miejskim i wolnością osobistą mieszkańców, ale mającymi niekiedy obowiązek pańszczyźniany względem właściciela ośrodka, który mógł też ograniczać jego samorządnośćc ${ }^{56}$. Miasta takie mogły stanowić centrum klucza dóbr ziemskich, jego

2010, s. 92; A. Karpiński, Żenska stużba domowa $w$ miastach polskich $w$ drugiej potowie XVI i w XVII w., w: Nędza i dostatek na ziemiach polskich od średniowiecza po wiek XX, red. J. Sztetyłł, Warszawa 1992, s. 41-61.

54 ANK, sygn. 47 (Dębowiec), s. 65-66 (1659).

55 C. Kuklo, Demografia Rzeczypospolitej..., s. 224-236.

56 Z. Noga, R. Szczygieł, Miasta prywatne w sieci miejskiej Królestwa Polskiego i Rzeczypospolitej Obojga Narodów. Uwagi wstępne, „Roczniki Dziejów Społecznych i Gospodarczych" 2016, t. 77, s. 9-10. 
administracji, punkt zbytu i wymiany towarowej dla swojego mikroregio$\mathrm{nu}^{57}$. Ośrodki takie stanowiły niemal codzienny kierunek dla okolicznej ludności wiejskiej, która mogła załatwić tam swoje sprawy urzędowe. Stąd, jak brzmi zapis w księdze wójtowskiej miasta Dębowiec z 1757 r.: „do prawa naszego wójtowskiego i akt naszych” stawiali się „personalnie pracowici ludzie", czyli chłopi w celu rejestracji transakcji nieruchomości wraz ze swymi urzędnikami i „świadkami wiejskimi”, jak też świadkami wywodzącymi się z miasta, w tym rajcami ${ }^{58}$. Zapisy takie pomagają rozpoznać wielowarstwowe sieci powiązań mieszkańców miast i wsi oraz ich tożsamość np. poprzez stanowione legaty ${ }^{59}$, obrót nieruchomości czy posagi ${ }^{60}$. Uwagę zwraca również rynek kredytowy, wiążący w wieloraki sposób mieszczan z chłopami i szlachtą. Nadto nawet postępująca agraryzacja miasteczek, jeżeli uniezależniała się w coraz większym stopniu od dostaw ze wsi, to niekoniecznie od zapotrzebowania na siłę roboczą ${ }^{61}$. Studia nad poszczególnymi ośrodkami miejskimi wskazują, na ile były one otwarte na ludzi z zewnątrz, na mieszkańców innych miast, a zwłaszcza okolicznych wsi ${ }^{62}$.

Grono zaledwie kilku wyrosłych w czasach średniowiecza miast dużych w Koronie i w Prusach w dobie wczesnonowożytnej powiększyła tylko Warszawa. Sam rozwój akcji lokacyjnej nie był równomierny, zwłaszcza odmiennie i z opóźnieniem następował na wschodnich połaciach Rzeczypospolitej. W większości pojawiały się tam miasteczka prywatne, w tym o charakterze obronnym. Liczba ówczesnych miast w całej Rzeczypospolitej pozostaje trudna do określenia, szacuje się ją na ok. 2000 dla połowy

57 P. Miodunka, Demograficzny i gospodarczy potencjat matych miast potudniowej Polski od końca XVI do początku XIX w., „Roczniki Dziejów Społecznych i Gospodarczych” 2017, t. 78, s. 131-161.

58 ANK, sygn. 47 (Dębowiec), s. 15-16; por. ibidem, s. 17, 40-41, 67-69, 107-109.

59 ANK, sygn. 324 [Księga cechu rzeźników w Proszowicach, 1653-1779], s. 102 (1762).

${ }^{60}$ Np. chłop z Niegosławic pod Dębowcem, który wydał jedną córkę za mieszczanina dębowieckiego, a drugą za mieszkańca swej osady, sam został w księdze określony na modłę miejską jako „obywatel niegłowski” (1760); ANK, sygn. 47 (Dębowiec), s. 93-94.

61 M. Bogucka, H. Samsonowicz, op. cit., s. 431, 446-448.

${ }^{62}$ W. Krawczuk, P. Miodunka, K. Nabiałek, Dzieje Wojnicza od XVI do XVIII w., Wojnicz 2009, s. 161-169. 
XVII w. ${ }^{63}$ Istotne dla badań nad migracjami pozostaje to, że ich stan zaludnienia nie przekraczał na ogół 1500 mieszkańców. W znanym podziale miast na cztery klasy (grupy) niewielkie ośrodki miały znaczną przewagę liczbową ${ }^{64}$. Tu warto zauważyć, że urbanizacja zachodu Europy to rozwój miast średniowiecznych, znajdujących się w gęstej sieci. W tym kontekście Europa Środkowo-Wschodnia, podobnie jak Skandynawia i Dania, prezentowała obszar „urbanizacyjnie zacofany” ${ }^{65}$, z miasteczkami mającymi niekiedy charakter efemeryczny, powstającymi zgodnie z wolą panów ziemskich na „surowym korzeniu”, trudnymi do odróżnienia od dużej wsi ${ }^{66}$. Tworzyły one jednak sieć rynków lokalnych wiążących okoliczne wsie, przez które przepływały towary, kapitał, siła robocza, a z tym wszystkim były związane sieci społeczne i migracje ${ }^{67}$.

Wobec powyższego przewagę liczbową małych miast można uznać za oznakę ożywienia gospodarczego, spowodowanego przez produkcję rolniczą wsi. Stąd też głównym kierunkiem dopływu nowych mieszkańców miasta były wsie, przy czym rosło zainteresowanie miastem wśród szlachty i magnaterii (nie tylko kwestie rezydencjonalne górnej warstwy tego stanu, ale i poszukiwanie zarobku przez uboższą szlachtę) $)^{68}$. Badania nad migracjami do miast są fenomenem w odniesieniu do Rzeczypospolitej przedrozbiorowej, państwa o charakterze zdecydowanie rolniczym, z dominującą liczebnie ludnością chłopską (stanowiącą według szacunków 70\% ogółu ludności), poddaną obciążeniom pańszczyźnianym i (przynajmniej

63 C. Kuklo, Demografia Rzeczypospolitej..., s. 225-236.

64 M. Bogucka, H. Samsonowicz, op. cit., s. 351, 357, 370-385.

65 Ibidem, s. 379-380.

66 R. Szczygieł, Miasta prywatne w Polsce od XIV w. do 1772 r. - chronologia lokacji, wtaściciele, petnione funkcje, „Roczniki Dziejów Społecznych i Gospodarczych” 2016, t. 77, s. 13-45; F. Kiryk, Lokacje miejskie nieudane, translacje miast i miasta zanikte w Matopolsce do potowy XVII stulecia, „Kwartalnik Historii Kultury Materialnej” 1980, R. 28, z. 3, s. 373-384.

67 Zob. J. M. Małecki, op. cit., s. 60-101; por. J. Maroszek, Targowiska wiejskie w Koronie Polskiej $w$ drugiej potowie XVII i XVIII w., Białystok 1990.

68 C. Kuklo, Demografia Rzeczypospolitej..., s. 225-236, 261-267; M. Bogucka, H. Samsonowicz, op. cit., s. 390. 
teoretycznie) o ograniczanym odgórnie wychodźstwie ze wsi ${ }^{69}$. Zauważmy, że dalsze 20\% mieszkańców było mieszczanami, wywodzącymi się w dużej mierze $\mathrm{z}$ rodzin chłopskich ${ }^{70}$.

Liczbowo dominowali migranci wewnętrzni, a zasięg napływu zależał od wielkości ośrodka, przy czym na ogół oscylował na dystansie kilkunastu-kilkudziesięciu kilometrów. Nawet ok. połowę ludności osiadającej w miastach stanowili przybysze $\mathrm{z}$ najbliższych jego okolic, w odległości do 20-30 km. Albo się w tych okolicach urodzili, albo było to ich poprzednie miejsce dłuższego pobytu i zatrudnienia ${ }^{71}$. Migracje te były to $\mathrm{z}$ reguły przemieszczenia wiejsko-miejskie, niekiedy podlegające etapowaniu ze wsi przez miasteczko do większego ośrodka, dotyczące zwłaszcza ludzi młodych o chłopskich korzeniach. Dla poznania intencji migrantów stosuje się tutaj bilans czynników wypychających ich z miejsca zamieszkania i przyciągających gdzie indziej. Młodością tłumaczy się próby usamodzielnienia zawodowego, edukacji, poszukiwanie współmałżonka, lepsze pespektywy poza środowiskiem rodzinnym. Dla potomków chłopów pańszczyźnianych wiązało się to również z osiągnięciem, może kuszącej niektórych, wolności osobistej. W ten sposób, budując przez całe pokolenia sieci migracyjne, chłopi i wywodząca się z tej grupy społecznej znaczna część ludności małomiasteczkowej tworzyli w większych miastach zaplecze produkcyjne i demograficzne.

W konsekwencji najsilniejsza strefa napływu ludności do miasta, a zarazem jego zaplecze demograficzne, odbijała zasięg strefy żywicielskiej danego ośrodka oraz funkcjonowania rynku lokalnego ${ }^{72}$. Dynamika i siła

69 O tak naprawdę formalnym znaczeniu poddaństwa w XVIII-wiecznych Czechach pisze J. Grülich, Migrační strategie...

70 C. Kuklo, Demografia Rzeczypospolitej..., s. 220-221, 224-236, 261-267; M. Bogucka, H. Samsonowicz, op. cit., s. 359-362.

71 J. Lucassen, L. Lucassen, Theorizing cross-cultural migrations: the case of Eurasia since 1500, „Social Science History” 2017, vol. 41 (3), s. 445-475; A. Walaszek, op. cit., s. 172; J. Grülich, Migrace mestskeho..., s. 208; M. Wyżga, Homo movens..., s. 103-104; zob. Gated communities? Regulating migration in early modern cities, eds. B. De Munck, A. Winter, Farnham 2012.

72 Można do tego odnieść teorię niemieckiego geografa Walthera Christallera o oddziaływaniach miast (Central Place Theory). Nadto teorię stref rolniczych (kręgów) ekonomisty Johanna Heinricha von Thünena, w której dowodził on zależności rozwoju gospodarczego 
migracji zależała od bieżącej koniunktury gospodarczej miasta i jego mikroregionu $^{73}$. Wreszcie warto zauważyć, że w państwie o utrzymującym się systemie folwarczno-pańszczyźnianym i politycznej dominacji szlachty, jakim była Rzeczypospolita przedrozbiorowa, miasta w pewnym stopniu dekomponowały jego ustrój. $Z$ jednej strony jako centra migracyjne oferowały chłopom awans społeczny, z drugiej szlachcie podejmującej się zajęć mieszczańskich mogły przynieść degradację stanową ${ }^{74}$. Nadto warto zwrócić uwagę na chłopsko-mieszczańskie sieci społeczne, gdyż oba stany były w pewnym stopniu upośledzone prawnie w dawnej Polsce, co w jakiejś mierze wyróżnia je na tle innych części ówczesnej Europy.

Dla efektywnego zarządzania przepływem ludności miasta wypracowywały mechanizmy, których precyzyjnym narzędziem było nadawanie obywatelstwa miejskiego. Stąd też polityka migracyjna, realizowana głównie na poziomie właściciela ośrodka, rady miejskiej czy zrzeszeń cechowych, określała możliwość udziału w pełnoprawnym członkostwie komuny miejskiej. Przepisami starano się również powstrzymać chłopów niezwolnionych z poddaństwa przed nabywaniem nieruchomości (np. w Wojniczu w 1607 r. $)^{75}$. Uzyskanie obywatelstwa w danym ośrodku miejskim automatycznie anulowało posiadanie tegoż $\mathrm{w}$ innym ${ }^{76}$. Jednak miasta składały się przede wszystkim z ruchomej masy mieszkańców pozbawionych tych

w uzależnieniu od bliskości rynku zbytu, a także funkcjonowania stref żywicielskich wokół miast; E. Nowosielska, Teoria Christallera - prawda i mity: (w sprawie nieporozumień pojęciowych), Warszawa 1992; W. Zgliński, Ksztattowanie się strefy żywicielskiej Aglomeracji Warszawskiej, Instytut Geografii i Przestrzennego Zagospodarowania PAN, Prace Geograficzne 162, Wrocław 1994.

73 M. Wyżga, Homo movens..., s. 195-209; zob. Rynki lokalne i regionalne $w$ XV-XVIII, red. P. Guzowski, K. Boroda, Kraków 2013.

74 Inną kwestią jest działalność szlachty zamożnej, która nabywała nieruchomości w mieście i na przedmieściach, tworząc pałace i jurydyki wyłączone z jurysdykcji miejskiej; zob. T. Zielińska, op. cit.; por. J. Wiesiołowski, Szlachta w mieście. Przemieszczenia i migracje szlachty między wsia a miastem $w$ Polsce XVw. ,Studia i Materiały do Dziejów Wielkopolski i Pomorza" 1980, t. 14, z. 1, s. 47-75; F. Kiryk, Szlachta w Bochni..., s. 71-124.

75 W. Krawczuk, P. Miodunka, K. Nabiałek, op. cit., s. 125-127.

76 O Wojciechu Kurkiewiczu zapisano ok. 1760 r.: „[...] świeżo przybyłym z miasta Słomnik mieszczaninem i rzeźnikiem, a teraz miasta Proszowic [...] mieszczaninem i posesorem”; ANK, sygn. 324 [Księga cechu rzeźników...], s. 104. 
przywilejów, jak również osób pojawiających się okresowo w związku z podejmowanym zatrudnieniem czy poszukiwaniem wsparcia socjalnego.

Mieszczanie dobrze znali najbliższą okolicę, gdzie byli powiązani rodzinnie i zawodowo z chłopami, skąd niejednokrotnie sami pochodzili. Prócz tego budowali bliższe relacje z ludnością chłopską wzdłuż traktów, którymi podążali na targi i jarmarki do innych miast. Mobilność mieszczan w mniejszych miastach polskich, łącząca się z pracą codzienną, dostawami i handlem, nawet w braku szczegółowych rejestrów przewozów i cła jest możliwa do przybliżenia na podstawie spraw spornych i zawieranych kontaktów ${ }^{77}$. Pojawiają się m.in. informacje o „spółkach” kupieckich, wiążących chłopów i mieszczan na kilkudziesięciokilometrowych dystan$\operatorname{sach}^{78}$. Pozwala to przy odpowiednej obróbce na odtworzenie geografii życia codziennego mieszczan, ich więzi rodzinnych i zawodowych, które były zalążkiem procesów migracyjnych lub im towarzyszyły. Przykładowo, na podstawie ksiąg miejskich, posługując się m.in. rejestrami przyjęć nowych obywateli i kryterium nazwiskowym osób zapisywanych w księgach, Feliks Kiryk wskazał na osadników w Lipnicy czy Jordanowie, kupców i przewoźników docierających do Biecza, nowych obywateli Czchowa wywodzących się z całej Polski, ale z przewagą okolicznej ludności wiejskiej, wreszcie wpływ osadnictwa pasterskiego na przewagę wyznania greckokatolickiego w Miastku ${ }^{79}$. Miasta podgórskie, jak Żmigród Nowy, stanowiły punkt etapowy dla kupców przemieszczających się między miastami polskimi i ślą-

77 Przykładowo starszy proszowickiego cechu rzé́ników zaskarżył innego rzeźnika o podkupienie partii zwierząt od chłopa z odległej o $13 \mathrm{~km}$ w stronę Krakowa wsi Pietrzejowice. Sprawa miała być wyjaśniona w ratuszu proszowickim w obecności tegoż chłopa. Zaznaczono jednak, że kwestia ta nie jest „w interesie” dworu pietrzejowickiego. Wskazuje to na dobrowolność kontaktów gospodarczych między chłopami poddańczymi a mieszczaństwem; ANK, sygn. 324 [Księga cechu rzeźników...], s. 30 (1724). Por. kłótnie między mieszczanami proszowickimi, którzy spotkali się na drodze przy wsi Chorążyce; ibidem, s. 39 (1759).

${ }^{78}$ Np. handlarze wołów; ANK, sygn. 47 (Dębowiec), s. 156 (1752); zob. C. G. Pooley, Mobility, migration and transport: historical perspectives, Lancaster 2017.

79 F. Kiryk, Rozwój urbanizacji Matopolski XIII-XVI w.: województwo krakowskie (powiaty potudniowe), Kraków 1985, s. 40, 116, 130-131, 236-237; por. D. Burdzy, Podróże mieszczan sandomierskich $w X V I w$., w: Via viatores..., s. 103-114; K. Justyniarska-Chojak, Mieszczanin w podróży (w świetle testamentów i inwentarzy pośmiertnych z terenu Matopolski 
skimi a ośrodkami północnych Węgier (Bardiów, Debreczyn, Koszyce, Preszow). Sieci społeczne powiązane $\mathrm{z}$ handlem, transportem czy edukacją rzemieślniczą spajały więc nie tylko okoliczne wsie i miasta, ale i dalsze obszary $^{80}$.

Zjawiska migracyjne trudne do oszacowania nawet we współczesnym świecie tym bardziej stanowią problem dla epok minionych. Z racji specyfiki materiałów źródłowych łatwiej ukazać napływ niż odpływ ludności w mieście. Nadto miasta miały swoje lokalne cechy, indywidualizm wykształcony np. przez stan prawny i własnościowy, usytuowanie w danym regionie, co wpływa na złożoność analizy procesów migracji ${ }^{81}$. Istnieje tu wiele koncepcji badawczych ${ }^{82}$, jednak tylko częściowo mogą być one zastosowane dla okresu przedprzemysłowego. Ponieważ jednak pewne elementy migracji są podobne, ośmiela to do podejmowania prób wykorzystania rozwiązań analitycznych stosowanych dla współczesności. Tu można nawiązać do metody etnosondażu Douglasa Masseya, polegającej na połączeniu i naprzemiennym stosowaniu metod ilościowych i jakościowych, co pozwala na ich wzajemną kontrolę ${ }^{83}$. Wspomniana metoda dotyczy również badania społeczności lokalnej migranta (miejsce wyjścia), przy założeniu, że plany migracyjne powstają głównie na oddolnym poziomie rodzinnych gospodarstw domowych i społeczności lokalnych. Można wykorzystać elementy metody biograficznej (a także tzw. biografii zwielokrotnionej opartej na historiach życia), umożliwiającej wgląd w intencje badanych jednostek

w XVI-XVII w.), w: ibidem, s. 115-124; M. Międzybrodzka, Gospodarka i polityka solna wyznacznikiem szlaków handlowych i relacji spotecznych, w: ibidem, s. 125-139.

${ }^{80}$ F. Kiryk, Rozwój urbanizacji..., s. 85-89, 98; W. Krawczuk, P. Miodunka, K. Nabiałek, op. cit., s. 241-244, 422-433.

${ }_{81}$ M. Okólski, A. Fihel, Demografia. Wspótczesne zjawiska i teorie, Warszawa 2012, s. 108.

${ }^{82}$ Zob. np. W. Janicki, Przeglad teorii migracji ludności, „Annales Universitatis Mariae Curie-Skłodowska” 2007, Sekcja B, t. LXII/14, s. 285-304.

${ }^{83}$ A. Górny, Wybrane zagadnienia podejścia jakościowego w badaniach nad migracjami, „Prace Migracyjne” 1998, nr 20, s. 12, 16-21; E. Jaźwińska, W. Łukowski, M. Okólski, Etnosondaż lokalny i regionalny, czyli o metodzie Ośrodka Badań nad Migracjami UW, w: Wspótczesne migracje: dylematy Europy i Polski, red. M. Duszczyk, M. Lesińska, Warszawa 2009, s. 82-91. 
i grup społecznych ${ }^{84}$. Do obserwacji przepływów siły roboczej można też odnieść teorię migracji dualnego rynku pracy Michaela Piore’a. Mówi ona o podziale wykonywanego przez ludzi miejscowych i migrantów zatrudnienia względem wysokości płac, jakości pracy i jej charakteru ${ }^{85}$. Wreszcie interesująca jest obserwacja postępów naturalizacji migranta w nowym środowisku oparta na modelu akulturacji kanadyjskiego psychologa Johna Berry' ego ${ }^{86}$. Historycy społeczni stosują ją np. przy analizie ksiąg metrykalnych ślubów, przy rozróżnieniu doboru małżeńskiego na endogamię i egzogamię (związki zawierane wewnątrz i na zewnątrz danej grupy społecznej) ${ }^{87}$. Przy tym zwraca się uwagę na migracje w kontekście transferu umiejętności i produkcji, strategie docierania migrantów do miasta i przeżycia w nim. Wyróżnia się następujące składniki tego procesu: tożsamość, wzajemne wsparcie i asymilację, a także strukturę społeczności „mobilnych”. Nadto aktualne w badaniach historii migracji są kwestie społecznej inkluzji i ekskluzji migrantów przybywających do miast. Na ile przybysze byli zdolni do zaadaptowania się do nowych warunków, czy odnosili sukcesy na rynku pracy, czy byli w stanie zakładać sieci społeczne lub wykorzystać już istniejące, czy utożsamiali się z nowym miejscem pobytu i zastanymi tam

84 Por. T. Wiślicz, Upodobanie. Matżeństwo i związki nieformalne na wsi polskiej XVII-XVIII w. Wyobrażenia spoteczne i jednostkowe doświadczenia, Wrocław 2012, s. 17-33.

85 M. Skoczek, Migracje jako czynnik rozwoju wielkich miast, w: Migracje i wielkie metropolie, t. 15: Migracje i spoteczeństwo, red. J. E. Zamojski, Warszawa 2012, s. 7.

86 S. Bozzolo, C. Costamagna, L. Fontana, Europejskie tożsamości, migracja i integracja: mtodzi europejscy migranci w dwóch zachodnich metropoliach, „Człowiek i Społeczeństwo" 2014, t. 37: Miasta i migracje, s. 163-164.

$87 \mathrm{~W}$ ten sposób zastosowano to do obserwacji europejskich miast w XIX w., dzieląc zawierane w mieście małżeństwa, w efekcie których doszło najpewniej do asymilacji (migrant + miejscowy), integracji (migrant + migrant $\mathrm{z}$ innych stron), separacji (migrant + migrant z tej samej okolicy) oraz degradacji (pozostanie migranta w stanie bezżennym). Przy okazji daje się poznać przez np. charakterystykę świadków ślubu, krąg rodzinny, zawodowy i towarzyski (sieć społeczna) migranta. Argumentem za wiarygodnością tej metody jest powszechność zawierania małżeństw w minionych epokach; P. Puschmann, N. Van den Driessche, K. Matthijs, B. Van de Putte, Paths of acculturation and social inclusion. Migration, marriage opportunities and assortative mating by geographic origin in Antwerp, 1846-1920, „Journal of Migration History” 2016, vol. 2 (1), s. 177-207. 
grupami społecznymi, czy przyłączali się do nich lub może tworzyli własne. Wreszcie, czy doświadczali dyskryminacji i sobie z nią radzili ${ }^{88}$.

Jak już wskazaliśmy, dla pełniejszego obrazu zjawisk migracyjnych ciągi liczbowe ludności, których wzrosty i spadki są związane z fluktuacjami i bieżącą sytuacją miast, powinny być obudowane analizą jakościową, przede wszystkim dotyczącą jednostek, ich środowisk lokalnych. Trzeba też mieć na uwadze miejsce migracji w danym cyklu życia jednostki, wpływ rodziny na migranta i kolejność opuszczania domu przez potomstwo, przewagę migracji z najbliższej okolicy miasta, etapowość migracji (wieś-miasteczko-przedmieście-miasto) ${ }^{89}$, działalność sieci migracyjnych (naturalizowani migranci ściągający znajomych do miasta jako zaufanych pracowników) i budowanie dobrej reputacji przybysza w mieście, wreszcie wpływ handlu i wahań w wysokości płac, podaży i popytu pracy na migracje ${ }^{90}$.

Dla miasta epoki przedprzemysłowej problemem jest określenie salda migracji i obrotu migracyjnego, tj. różnic między napływem a odpływem ludności. Przed badaczami migracji stoi również świadomość żmudnej budowy elektronicznych baz danych oraz mapowania dostrzeganych zjawisk. Należy przy tym mieć na uwadze, że większość migracji miała charakter tymczasowy ${ }^{91}$. Migranci byli nie tylko fizycznie „w drodze”, równocześnie zmieniała się w jakimś stopniu ich tożsamość i doznawali większej lub mniejszej akulturacji w kolejnych miejscach pobytu ${ }^{92}$. W dotychczasowych badaniach światowych skupiano się głównie na określaniu miejskiej polityki migracyjnej wobec konkretnych grup przybyszy. Na uboczu pozostawali migranci trudni do precyzyjnego zdefiniowania, zwłaszcza w kontekście zmieniających się $\mathrm{w}$ zależności od koniunktury mechanizmów ich

88 A. Górny, op. cit., s. 16-21.

89 Dotyczy to zwłaszcza ludzi uboższych, jak służba domowa; M. Kołacz-Chmiel, Mulier honesta..., s. 311-312.

90 M. Malinowski, Serfs and the city: market conditions, surplus extraction institutions and urban growth in Poland, 1500-1772, „European Review of Economic History” 2016, vol. 20 (1), s. 123-146.

91 B. de Munck, A. Winter, Regulating migration in early modern cities: an introduction, w: Gated Communities..., s. 1-22.

92 Podobne wnioski przynoszą badania nad współczesnymi migracjami do miast; zob. Migracje i wielkie... 
przyjmowania i wydalania. Podobnie nie uwzględniało się powiązania polityki inkluzji i ekskluzji z poszczególnymi typami miejskich organów decyzyjnych, jak rady miejskie, cechy czy przedstawicielstwa innych organizacji charakterystycznych dla danego ośrodka (administracja opieką społeczną, państwo i władze lokalne, Kościół, korporacje zawodowe, zgromadzenia publiczne i ich przedstawicielstwa). Nie są oczywiste granice rozdzielania przybyszy na chcianych i niechcianych. Podlegały one zmianom w czasie, różniły się ze względu na obszar i bieżące potrzeby komun miejskich. Regulacje odnośnie do migracji były często „produktem ubocznym” interwencji władz miasta w rynek pracy, mieszkalnictwo, porządek publiczny czy opiekę społeczną. To wszystko wypada uwzględnić $\mathrm{w}$ badaniach nad migracjami do i z miast ${ }^{93}$.

W ten sposób celem staje się obserwacja cyrkulacji i alokacji siły roboczej, dóbr i kapitału, ruchliwości społecznej i osadnictwa. Istotną kwestią jest, że wahania popytu i podaży na niestabilnym miejskim rynku pracy mogły przekształcać ludzi pożytecznych w zbędnych i odwrotnie. Sprowadzanie nowej siły roboczej było stymulowane przez działające już $\mathrm{w}$ mieście grupy produkcyjne i robotnicze. Cechy rzemieślnicze mogły wpływać na władze miejskie w kwestii regulacji zatrudnienia oraz dystrybucji zasobów produkcyjnych. Korporacje te w czasie niestabilności rynku zamykały się, ale w dogodnych okresach otwierały na przybyszy, zwłaszcza jeżeli synowie mistrzów mieli perspektywy awansu poza cechem, i powstawały w ten sposób nowe oferty pracy ${ }^{94}$. Cechy rzemieślnicze zabezpieczały się w kwestiach naboru nowych pracowników. Czeladnicy pilnowali z kolei, by to najpierw ich zatrudniano, jeszcze przed niewyzwolonymi lub rękodzielnikami działającymi poza korporacją. Podobnie opór przed kolejnymi migrantami w obawie utraty miejsc pracy czy spadkiem stawek mogli stawiać obecni już w mieście pracownicy dniówkowi. Wiadomo, że mimo tych zjawisk niektórzy rzemieślnicy woleli pozostać poza cechem, by być bardziej elastycznymi wobec zmieniających się warunków rynku pracy (tak było np. w Genui czy Strasburgu). Wreszcie, osoby planujące pobyt czasowy z racji szacowanych kosztów wolały nie angażować się w procedurę wej-

93 B. de Munck, A. Winter, op. cit., s. 4-5.

94 Ibidem, s. 7. 
ścia w struktury miejskie. Różnie wyglądały też relacje między instytucjami miejskimi a zewnętrznymi wobec migracji i rynku pracy. Różniły się one w poszczególnych miastach Europy. Niekiedy bieżące cele polityczne władz wyrastały ponad istniejące przepisy i wpływały na regulację migracji ${ }^{95}$.

W analizie należy także uwzględnić rozmaite interesy migrantów w mieście: edukację, zatrudnienie, handel, wreszcie znalezienie współmałżonka, założenie rodziny i zamieszkanie w mieście, a także szukanie opieki przez przybywające tam z prowincji (np. za migrującymi i osiadłymi w mieście dziećmi) osoby starsze i chore czy współmałżonka, niejednokrotnie przy pomocy osiadłych w mieście członków dawnej społeczności wiejskiej, krewnych, sąsiadów i znajomych. Niewątpliwie trzeba wiązać przepływy migracyjne $\mathrm{z}$ obrotem handlowym i kredytowym, a także przepływem usług. Te wahadłowe, codzienne lub cotygodniowe, rytmiczne przemieszczenia, niekiedy (jak wynika z naszych badań nad Krakowem) przekraczające odległość $50 \mathrm{~km}$, były podłożem dla znalezienia przez chłopów sezonowej pracy (np. w nieproduktywnym okresie zimowym). To również pozwalało uzgodnić z mieszczaństwem przyszłość zawodową chłopskich dzieci w mieście. W ten sposób przez lata tworzyły się zasoby zaufanej siły roboczej w miastach, pozwalające na dość szybką odbudowę demograficzną po przejściu klęski elementarnej.

Należy również zwrócić uwagę, na ile dystans między osadą pochodzenia a miastem wpływał na istnienie barier kulturowych i ich obalanie, na siłę i trwałość sieci migracyjnych gwarantujących potrzebne migrantowi wsparcie i rękojmię przed pracodawcami i urzędami. Wydaje się, że negatywne emocje odnośnie do pochodzenia ze wsi w małym mieście, gdzie kwestia anonimowości przybysza nie była tak oczywista, jak w Warszawie czy Lublinie, miała pewne znaczenie, zwłaszcza jednak „zadanie poddaństwa”, czyli nierozliczenie stosunku poddańczego w opuszczonej wsi. Takie „inwektywy” padały np. w trakcie kłótni mieszczańskich w Uściu Solnym w połowie XVIII w. ${ }^{96}$ Pejoratywny wydźwięk miało również określenie

95 Ibidem, s. 9.

96 ANK, sygn. DEP 467, Księga radziecko-ławnicza miasta Uście Solne 1742-1743, s. $17-18,25-26,31-35$. 
"Góralu”"97 czy „Miemko"98, odnoszące się w pewnym stopniu do pochodzenia.

Czeka na swoich badaczy również migracja i rynek pracy w podejściu do płci kulturowej. Dla tego zamierzenia należy zintensyfikować badania nad rynkiem pracy kobiet, które nie tylko funkcjonowały w gospodarstwach domowych jako gospodynie czy służba domowa, ale również w handlu (na ogół drobniejszym), rzemiośle, pracach najemnych (np. budowlanych) czy transporcie, co wskazuje na ich mobilność ${ }^{99}$. Niedoceniania dotąd rola kobiet $\mathrm{w}$ historii migracji jest ostatnio podnoszona ${ }^{100}$. W przypadku Rzeczypospolitej kobiety pojawiają się $\mathrm{w}$ rachunkach miejskich (np. jako pomoc przy budowie), w rejestrach szpitalnych (mamki, opiekunki) czy w handlu detalicznym. Ponadto informacje o ruchliwości przestrzennej kobiet zawierają księgi metrykalne (egzogamia małżeńska czy rola kobiet w charakterze matek chrzestnych ${ }^{101}$, księgach szosu czy w różnych innych kategoriach ksiąg miejskich (np. w związku z dziedziczeniem, obrotem nieruchomości), gdzie proporcje udziału pod kątem płci nie są wcale aż tak zróżnicowane (jeżeli weźmiemy sprawy wszczynane przez kobiety przez swych plenipotentów). Także mężczyźni zawierający transakcje, np. ojcowizną, dokonywali ich za konsensem z małżonką (np. w podgórskim mieście Dębowiec

97 Ibidem, s. 55.

98 ANK, sygn. 47 (Dębowiec), s. 73-73a; por. W. Krawczuk, P. Miodunka, K. Nabiałek, op. cit., s. 167, 235-239.

99 Według instrukcji rajców miasta Pszczyna z 1761 r. do piwowarów: „Piwo tesz żeby sami Tragarze, a nie zony Jeich, nosili, a jeżeliby z słusznych prziczyn sami nosić niemogli, żeby na swe mieysce, nie Żony ale mężczyzny zasadzili”; Instrukcje rajców miejskich Pszczyny z XVII w., wyd. D. Rott, A. Spyra, Perty stowa polskiego na Ziemi Pszczyńskiej, t. 6, Pszczyna 2013, s. 14; M. Kołacz-Chmiel, Mulier honesta..., s. 281, 301-315; eadem, Migracje kobiet z rodzin chtopskich $i$ ich przyczyny $w$ Polsce $X V w$. ( $w$ świetle ksiag oficjata lubelskiego), w: Via viatores..., s. 303-315.

100 N. L. Green, Changing paradigms in migration studies: from men to women to gender, „Gender \& History” 2012, vol. 24 (3), s. 782-798.

101 J. Keskinen, The chosen ones: godmotherhood as a networking strategy in the Merchant Community of Pori, 1765-1820, w: Female agency in the urban economy. Gender in European towns, 1640-1830, eds. D. Simonton, A. Montenach, New York 2013. 
używano formuły: „naradziwszy się z małżonką swoją”, ale i z siostrami czy dziećmi $)^{102}$.

\section{Zakończenie}

W artykule przybliżono stan badań nad migracjami do miast przedprzemysłowych oraz niektóre możliwości źródłowe i badawcze, jak również ograniczenia w tym kierunku dla ziem polskich. Badanie migracji w kontekście miast Rzeczypospolitej przedrozbiorowej oprócz ujęcia podstawowych, zdatnych do odtworzenia na podstawie dostępnej bazy źródłowej zjawisk, jak sieci społeczne i polityka migracyjna, wymaga rozpoznania specyfiki rynków lokalnych, więzi wiejsko-miejskich funkcjonujących w realiach systemu folwarczno-pańszczyźnianego, gdzie część chłopów przynajmniej formalnie była przypisana do ziemi. Należy również zwrócić baczniejszą uwagę na sytuację kobiet na rynku pracy i związanych z nim przemieszczeń, starać się adaptować nowe lub nieużywane dotąd w tym kierunku materiały źródłowe. Za setkami zarejestrowanych mężczyzn jako nowych obywateli miast stały ich żony, córki, matki i siostry, służba domowa oraz pracownicy, będący tylko z pozoru w sferze „milczenia źródeł”. Wreszcie, należy rozważyć, czy bardziej reprezentują specyfikę Rzeczypospolitej dobrze zachowane i urozmaicone archiwalia nielicznych dużych, samorządnych miast królewskich, czy częstokroć fragmentaryczne, skupiające się nieraz w jednej księdze rozmaite sprawy akta miasteczek i okalających je wsi. Osobnej koncepcji wymaga ujęcie zawartych w nich informacji w bazy danych, pozwalające w dalszym etapie na powiązanie danych migrantów w świetle różnych źródeł, z różnych ośrodków miejskich i wiejskich. Studium migracji winno mieć wszechstronny ogląd zjawiska w świetle różnych źródeł, co zaś kieruje ku gruntownym badaniom uwzględniających różnice regionalne i ku analizie miasta w kontekście jego mikroregionu ${ }^{103}$. Relacyjne łączenie danych masowych z różnego typu materiałów, zestawionych w bazie elektronicznej

102 ANK, sygn. 47 (Dębowiec), s. 17, 34, 40-41.

103 Por. C. Kuklo, Demografia Rzeczypospolitej..., s. 261, 267; J. Lucassen, L. Lucassen, op. cit., s. 445, 475; L. P. Moch, Conclusions, w: Gated Communities..., s. 241-244. 
i odnoszących się do konkretnych migrantów i ich rodzin, pozwala na odtwarzanie historii życia. Źródła ilościowe mogą być dla badanej epoki zawodne z racji ich wiarygodności i luk w ciagach chronologicznych, pozostają jednak cenne w wymiarze komparatystycznym. Źródła narracyjne charakteryzują z kolei procesy migracyjne „od wewnątrz”, pozwalają poznać lepiej motywy i sytuację osobistą migrantów. 
